\title{
PERAN STAKEHOLDER DALAM MANAJEMEN BENCANA BANJIR
}

\author{
Oleh: \\ Syahputra Adisanjaya Suleman ${ }^{\mathbf{1 7}}$, Nurliana Cipta Apsari ${ }^{\mathbf{1 8}}$
}

\begin{abstract}
ABSTRAK
Indonesia merupakan wilayah rawan bencana alam. Bencana selalu terjadi di sepanjang wilayah Indonesia, dari barat hingga timur. Menurut International Strategy for Disaster Reduction (UN-ISDR2002,2004) bencana alam adalah suatu kejadian, yang disebabkan secara alamiah atau karena ulah manusia, dan terjadi secara tiba-tiba atau perlahan-lahan, sehingga menyebabkan hilangnya jiwa manusia, harta benda, dan kerusakan lingkungan. Kejadian bencana yang terjadi secara tiba-tiba ini menuntut masyarakat untuk selalu siap siaga dalam menghadapi bencana yang sewaktu-waktu dapat terjadi. Kesiap-siagaan dalam menghadapi bencana ini termasuk ke dalam ranah manajemen bencana banjir. Banyak pihak yang perlu terlibat dalam manajemen bencana, yaitu pemerintah, pihak swasta dan masyarakat itu sendiri.

Desain penelitian adalah kualitatif, dengan metode pengumpulan data adalah studi kepustakaan. Pengumpulan data sekunder dan kajian pustaka (literatur), didefinisikan sebagai penelusuran yang dilakukan oleh peneliti terhadap sumber pendukung untuk kepentingan penelitian yang sedang dijalankan.

Peran stakeholder dalam manajemen bencana banjir yang dalam hal ini dilakukan oleh pemerintah pusat, pemerintah daerah, BNPB dan lembaga swasta dan international telah diatur dalam peraturan pemerintah. Instansi/institusi mempunyai tugas, fungsi, dan perannya masing-masing sesuai peraturan yang telah ditetapkannya. Namun dapat dilihat dari tugas, fungsi dan perannya, bahwa BNPB/BPBD mempunyai peran yang secara langung berwenang dalam penanganan bencana, khususnya pada mitigasi bencana banjir. Hal ini didasarkan pada pembentukan lembaga BNPB/BPBD sebagai pusat dalam penanggulangan bencana nasional dan daerah.
\end{abstract}

\section{Kata kunci: Peran, Stakeholder, Manajemen Bencana}

\section{PENDAHULUAN}

Bencana alam merupakan suatu kejadian yang tidak dapat diprediksi kapan akan terjadi, iklim yang tidak menentu seringkali berdampak pada terjadinya bencana alam yang datang dengan tiba-tiba. Di Indonesia pada umumnya merupakan wilayah rawan bencana alam, hampir disetiap tahun di setiap daerah mengalami berbagai bencana alam. Menurut International Strategy for
Disaster Reduction (UN-ISDR-2002,2004) bencana alam adalah suatu kejadian, yang disebabkan oleh alam atau karena ulah manusia, terjadi secara tiba-tiba atau perlahanlahan, sehingga menyebabkan hilangnya jiwa manusia, harta benda, kerusakan lingkungan, kejadian ini terjadi di luar kemampuan masyarakat dengan segala sumber dayanya. Sedangkan menurut UU No 24 Tahun 2007 Pasal 1 poin 1 , bencana adalah peristiwa atau

\footnotetext{
${ }^{17}$ Mahasiswa Pascasarjana Ilmu Kesejahteraan Sosial FISIP Unpad

${ }^{18}$ Dosen Departemen Kesejahteraan Sosial FISIP Unpad
} 
rangkaian peristiwa yang mengancam dan mengganggu kehidupan dan penghidupan masyarakat yang disebabkan, baik oleh faktor alam dan/atau non-alam maupun faktor manusia sehingga menyebabkan timbulnya korban jiwa manusia, kerusakan lingkungan, kerugian harta benda, dan dampak psikologis.

Bencana alam memberikan dampak yang sangat besar pada masyarakat, bahaya yang ditimbulkan sangat tidak dapat diperkirakan, bahaya adalah suatu fenomena alam atau buatan yang mempunyai potensi mengancam kehidupan manusia, kerugian harta benda dan kerusakan lingkungan (Nurjanah dkk, 2013). Menurut Badan Penanggulangan Bencana Nasional (BNPB) jumlah bencana alam yang terjadi di Indonesia pada tahun 2016 mencapai 1.907 kejadian, bencana tersebut antara lain adalah banjir, gempa bumi, letusan gunung api, putting beliung, kebakaran hutan dan lahan, tanah longsor dan banjir dan tanah longsor. Jumlah bencana alam yang banyak terjadi di Indonesia menandakan, bahwa dihampir seluruh wilayah Indonesia merupakan daerah rawan bencana alam dengan jenis bencana yang berbeda-beda. Pada kasus bencana alam, khususnya bencana banjir merupakan bencana yang paling banyak terjadi di Indonesia.

Bencana alam di Indonesia khususnya bencana banjir merupakan bencana dengan jumlah kejadian yang sangat besar serta menyebar dihampir seluruh wilayah. Banjir adalah limpahan air yang melebihi tinggi muka air normal, sehingga melimpah dari palung sungai menyebabkan adanya genangan pada lahan rendah di sisi sungai (Nurjanah dkk, 2013). Banjir disebabkan oleh curahan hujan yang berlebih sehingga menyebabkan sungai meluap kedaratan. Tidak adanya daerah resapan yang disebabkan oleh hutan gundul, penyempitan serta pendangkalan sungai mempengaruhi arus air sungai dari hulu ke hilir sehingga menyebabkan bencana banjir. Bukan hanya itu, sistem irigasi yang tidak baik serta penyumbatan oleh samapah pada aliran sungai dan irigasi membuat aliran air menjadi terhambat, hal ini merupakan fenomena ulah dari manusia yang tidak menjaga lingkungan sekitar dengan baik.

Persebaran bencana banjir hampir merata di seluruh wilayah Indonesia, dampak yang ditimbulkan juga sangat besar. Data BNPB sampai bulan Oktober tahun 2016 menyebutkan bahwa korban meniggal akibat bencana banjir mencapai 134 jiwa, korban luka-luka 104 jiwa, dan 2.210.114 jiwa menderita dan mengungsi. Jumlah korban yang terdampak bencana banjir berdasarkan data di atas sangatlah besar, sehingga penanganan bencana banjir di Indonesia perlu ditingkatkan. Bukan hanya korban jiwa, bencana banjir merusak rumah serta fasilitas umum, data BNPB sampai bulan oktober tahun 2016 menyebutkan bahwa rumah yang rusak berat berjumlah 2.071 unit, rusak sedang 1.018 unit, rusak ringan 5.242 unit, terendam 214.079 unit dan kerusakan fasilitas umum seperti fasilitas kesehatan 16 unit, fasilitas pendidikan 277 unit dan fasilitas peribadatan 199 unit. Jumlah kerusakan serta asset rumah yang dimiliki oleh masyarakat berdampak pada kerugian harta benda, oleh sebab itu pencegahan bencana banjir terus dilakukan dan ditingkatkan, mengingat dari tahun ke tahun dampak yang ditimbulkan sangatlah besar bagi masyarakat, khususnya masyarakat yang tingal di daerah rawan bencana banjir.

Manajemen bencana sangat perlu untuk ditingkatkan, khususnya pada bencana banjir, data BNPB menyebutkan sepanjang tahun 2016 bencana banjir merupakan bencana alam yang paling banyak menelan korban jiwa serta berdampak pada kerusakan rumah maupun fasilitas umum. Dampak bencana banjir sangatlah besar, oleh sebab itu manajemen bencana yang baik harus segera diterapkan. Menurut Carter (1991) penanggulangan bencana alam (disaster management) perlu diselenggarakan melalui tahap-tahap: Persiapan (preparation), Penghadangan/penanganan (Facing disaster), Perbaikan akibat kerusakan (reconstruction), Pengfungsian kembali prasarana dan sarana sosial yang rusak (Rehabilitation), dan Penjinak gerak alam yang menimbulkan bencana (Mitigation). Sedangkan menurut 
Nurjanah dkk (2013) Manajemen bencana adalah ilmu pngetahuan yang mempelajari bencana beserta segala aspek yang berkaitan dengan bencana, terutama resiko bencana dan bagaimana menghindari resiko bencana. Manajemen bencana merupakan proses dinamis tentang bagaiman bekerjanya fungsifungsi manajemen yang kita kenal selama ini misalnya fungsi planning, organizing, actuating, dan controlling.

Manajemen bencana banjir khusunya pada mitigasi diterapkan, guna untuk mencegah dampak dari bencana banjir. Mitigasi perlu untuk dilakukan untuk mengurangi resiko dari bencana banjir serta bisa untuk meningkatkan kemampuan masyarakat serta organisasi dalam penanganan bencana banjir. Menurut UU No 24 Tahun 2007 Mitigasi adalah serangkaian upaya untuk mengurangi risiko bencana, baik melalui pembangunan fisik maupun penyadaran dan peningkatan kemampuan menghadapi ancaman bencana. Kasus bencana banjir di Indonesia dampaknya sudah sangat parah, setahun terakhir ini kasus bencana banjir terjadi dimana-mana, data BNPB menyebutkan bencana alam yang terjadi di Indonesia sepanjang tahun 20116, 31,3\% adalah bencana banjir.

Mitigasi sangat berperan dalam pengurangan resiko bencana banjir, dengan mitigasi dampak bencana banjir dapat diminimalisir dengan baik. pengetahuan dan kemampuan masyarakat maupun stakeholder dapat menigkat dalam penanganan bencana banjir, sehingga korban jiwa, kehilangan harta benda serta dampak dari bencana banjir lainnya dapat ditangani. Mitigasi yang koprehensif perlu adanya peran stakeholder dalam penangannnya, karena tanpa peran stakeholder maka penyelenggaraan mitigasi dalam bencana banjir tidak akan berjalan. Dalam Pembagian Tanggung Jawab Manajemen Bencana pada UU No. 24 Tahun 2007, pemeritah pusat, pemerintah daerah, BNPB (Badan Nasional, Penanggulangan Bencana Nasional) lembaga usaha, dan lembaga international adalah lembaga yang bertanggung jawab dalam mitigasi bencana banjir. Oleh sebab itu mitigasi perlu dilakukan dengan peran dan fungsi masing-masing.

Pada penelitian oleh Farichatun Nisa Tentang "Manajemen Penanggulangan Bencana Banjir, Putting Beliung, dan Tanah Longsor di Kabupaten Jombang" mengemukakan Hasil penelitian menunjukkan bahwa manajemen penanggulangan bencana yang dilakukan oleh BPBD dilakukan melalui tahapan respon, pemulihan, dan pengembangan. Tahapan paling dominan yang dilakukan oleh BPBD Kabupaten Jombang melalui tindakan response sebelum dan sesudah terjadinya bencana. Sedangkan penanggulangan bencana yang dilakukan oleh masyarakat berupa partisipasi dalam bentuk buah pikiran, tenaga, harta benda, keterampilan, dan kemahiran, serta partisipasi sosial. Partisipasi yang dominan dilakukan oleh masyarakat adalah partisipasi tenaga dan partisipasi sosial. Dalam penelitian yang diuraikan dapat dilihat bahwa manajemen bencana banjir dilakukan melalui tindakan respon sebelum dan sesudah terjadinya bencana oleh BPBD. Kaitan dengan penelitian "Peran stakeholder dalam manajemen Bencana banjir" bahwa Peran dan fungsi stakeholder sangat dibutuhkan dalam manajemen bencana banjir khususnya dalam hal mitigasi, oleh karena itu penelitian ini hendak mengeksplorasi peran-peran yang dilakukan oleh stakeholder dalam Mitigasi Bencana Banjir, dengan stakeholder yang dimaksud adalah pihak pemerintah, pihak lembaga non pemerintah dan pihak swasta.

\section{METODE PENELITIAN}

Teknik pengumpulan data dalam penelitian ini adalah data sekunder. Pengumpulan data sekunder dan kajian pustaka (literatur), didefinisikan sebagai penelusuran yang dilakukan oleh peneliti terhadap sumber pendukung untuk kepentingan penelitian yang sedang dijalankan. Data sekunder memiliki tingkatan yang berbeda (Indrawan dan Yaniawati, 2014) yakni : (1) Tingkat pertama, yakni data sekunder dari sumber primer, seperti karya 
penelitian terdahulu, atau data mentah tanpa interpretasi atau pertanyaan yang mewakili suatu opini atau posisi resmi (belum pernah diolah atau ditafsirkan oleh pihak kedua). (2) Tingkat kedua, yakni data sekunder dari sumber sekunder, seperti interprestasi dari data primer. (3) Tingkat ketiga, yakni data sekunder dari sumber tersier seperti, interpretasi sumber sekunder yang pada umumnya disajikan dalam bentuk indeks, bibliografi, alat bantu pencarian data. Penelitian tentang Peran Stakeholder dalam Manajemen Bencana banjir menggunakan tingkatan yang ke dua, yaitu pengumpulan data merupakan data sekunder dari sumber sekunder, seperti interpretasi dari data primer.

\section{KAJIAN PUSTAKA}

Peranan (role) merupakan proses dinamis kedudukan (status). Apabila seseorang melaksanakan hak dan kewajibannya sesuai dengan kedudukannya, dia menjalankan suatu peranan. Perbedaan antara kedudukan dengan peranan adalah untuk kepentingan ilmu pengetahuan. Keduanya tidak dapat dipisah-pisahkan karena yang satu tergantung pada yang lain dan sebaliknya (Soekanto, 2009). Levinson dalam Soekanto (2009) mengatakan peranan mencakup tiga hal, antara lain: (1) Peranan meliputi norma-norma yang dihubungkan dengan posisi atau tempat seseorang dalam masyarakat. Peranan dalam arti ini merupakan rangkaian peraturan-peraturan yang membimbing seseorang dalam kehidupan bermasyarakat. (2) Peranan merupakan suatu konsep tentang apa yang dapat dilakukan oleh individu dalam masyarakat sebagai organisasi. (3) Peranan juga dapat dikatakan sebagai perilaku individu yang penting bagi struktur sosial masyarakat.

Peranan merupakan hal penting dalam kehidupan bermasyarakat, dengan menjalankan peran masing-masing, maka fungsi pokok individu dapat dijalankan dengan baik. Pada dasarnya individu memiliki peran yang berbeda-beda, baik yang diterapkan dalam diri sendiri, lingkungan masyarakat maupun institusi/organisasi dimana individu itu berada. Kaitannya dengan peran indiviudu dalam institusi/organisasi tentunya memiliki fungsi dan tanggung jawab sebagai pemangku kepentingan (stakeholder). Stakeholder merupakan pemangku kepentingan yang berperan dalam pengambilan keputusan serta memiliki kekuasaan dalam mempengaruhi individu, kelompok mapun organisasi. Menurut Budimanta dkk, 2008 Stakeholder merupakan individu, sekelompok manusia, komunitas atau masyarakat baik secara keseluruhan maupun secara parsial yang memiliki hubungan serta kepentingan terhadap perusahaan. Individu, kelompok, maupun komunitas dan masyarakat dapat dikatakan sebagai stakeholder jika memiliki karakteristik seperti yaitu mempunyai kekuasaan, legitimasi, dan kepentingan terhadap perusahaan.

Stakeholder merupakan pemangku kepentingan dalam pengambilan keputusan dan kekuasaan dalam mempengaruhi individu maupun organisasi, namun pada dasarnya peran stakeholder disesuaikan fungsi pokok dan tanggung jawabnya sebagai stakeholder. Berkaitan dengan peran stakeholder dalam bencana banjir, Undang-undang Nomor 24 Tahun 2007 tentang pembagian tanggung jawab manajemen bencana bahwa stakeholder yang berperan ialah pemerintah pusat, pemerintah daerah, BNPB (Badan Nasional Penanggulangan Bencana), lembaga usaha, dan lembaga internasional. Bencana banjir adalah limpahan air yang melebihi tinggi muka air normal, sehingga melimpah dari palung sungai menyebabkan adanya genangan pada lahan rendah di sisi sungai (Nurjanah dkk 2013).

Bencana banjir merupakan bencana yang terjadi karena diakibatkan oleh curah hujan yang tinggi, dimana daerah aliran sungai tidak dapat menampung debit air yang besar dan pada akhirnya meluap kedaratan. Pendangkalan serta penyempitan sungai menjadi faktor penyebabnya. Bukan hanya itu, adanya pembalakan liar yang mengakibatkan hutan gundul menjadi pengaruh yang sangat besar, hal ini membuat daerah resapan tidak maksimal sehingga bencana banjir tidak dapat terhindarkan. Penanganan bencana banjir membutuhkan manajemen bencana yang baik karena hal ini dapat meminimalisir dampak yang ditimbulkan. Manajemen bencana adalah ilmu pengetahuan yang mempelajari bencana 
beserta segala aspek yang berkaitan dengan bencana, terutama resiko bencana dan bagaimana menghindari resiko bencana.

Manajemen bencana merupakan proses dinamis tentang bagaimana bekerjanya fungsifungsi manajemen yang kita kenal selama ini misalnya fungsi planning, organizing, actuating, dan controlling (Nurjanah dkk,42:2013). William Nick Carter (1991) mengungkapkan bahwa penanggulangan bencana alam (disaster management) perlu diselenggarakan melalui tahap-tahap: Persiapan (preparation), Penghadangan/ penanganan (Facing disaster), Perbaikan akibat kerusakan (reconstruction), Pengfungsian kembali prasarana dan sarana sosial yang rusak (Rehabilitation), dan Penjinak gerak alam yang menimbulkan bencana (Mitigation). Prinsip praktis manajemen bencana (Nurjanah dkk, 45:2013) adalah sebagai berikut:
a. Cepat dan tepat
b. Prioritas
c. Koordinasi dan keterpaduan
d. Berdayaguna dan berhasil guna
e. Transparansi dan akuntabilitas
f. Kemitraan
g. Pemberdayaan
h. Non diskriminatif
i. Non-Proselitasi

\section{HASIL DAN PEMBAHASAN}

banjir $\begin{gathered}\text { Penyelenggaraan mitigasi bencana } \\ \text { seluruhnya dilaksanakan oleh }\end{gathered}$ pemerintah. Pemerintah bertanggung jawab penuh dalam penyelesaian masalah bencana, khususnya pada hal mitigasi bencana banjir. Peran dan tanggung jawab pemerintah telah diatur pada UU No. 24 Tahun 2007, bahwa penyelenggaraan tanggung penanggulangan bencana diserahkan pada pemerintah pusat, pemerintah daerah, dan BNPB (Badan Nasional Penanggulangan Bencana), namun pada pasal 28, 29, dan 30 UU No. 24 Tahun 2007 merumuskan lembaga usaha dan organisasi international dalam penanggulangan bencana baik secara sendiri mapun bersama-sama. Peran pemerintah pusat tersebar di berbagai Kementerian serta lembaga non kementerian, masing-masing mempunya fungsi dan peran dalam hal mitigasi bencana banjir.

Peran serta semua lembaga pemerintah dalam mitigasi bencana banjir menyebar dihampir seluruh instansi/institusi, baik kementrian maupun lembaga non kementrian. Hal ini menunjukan masing-masng lembaga mempunyai andil yang berbeda-beda dalam mitagasi bencana banjir. Penyelenggaraan mitigasi bencana banjir, setiap lembaga saling berkoordinasi antara satu sama lain. Selain pemerintah pusat, pemerintah daerah mempunyai peran dalam hal mitigasi bencana banjir, namun tugas dan fungsi yang dilakukan searah dengan pemerintah pusat. Perbedaan penanganan mitigasi bencana banjir antara pemerintah pusat daerah ialah pada tata letak wilayah, pemerintah pusat melaksanakan mitigasi secara menyeluruh di wilayah Indonesia, sedangkan pemerintah daerah pada daerah otonomnya sendiri.

Fungsi dan peran pemerintah daerah sangat jelas dalam mitigasi bencana banjir, pemerintah daerah meyusun rencana penanggulangan bencana meliputi, mitigasi, kegiatan pra bencana dan pasca benca. Kegiatan yang dilakukan oleh pemerintah daerah berkoordinasi pada semua instasi terkait yang mempunya fungsi dalam mitigasi bencana banjir. Pemerintah daerah juga melakukan koordinasi terhadap penyusunan rencana penanggulangan bencana banjir dengan BPBD, karena lembaga atau institusi BPBD mempunyai kewenangan lebih terhadap mitigasi bencana banjir. Pada dasarnya pemerintah daerah dan BPBD mempunyai kedudukan yang sama dalam penanganan mitigasi bencana banjir, BPBD sendiri merupakan bentukan dari BNPB yang dimana lembaga ini memiliki kewenangan yang besar terhadap penanggulangan bencana yang bertanggung jawab langsung pada Presiden.

\section{Badan Nasional Penanggulangan} Bencana (BNPB) dan Badan Penanggulangan Bencana Daerah (BPBD) mempunyai tugas dan fungsi yang langsung dalam kewenangan penanganan mitigasi bencana banjir. Secara khusus BNPB dan BPBD menjadi pusat 
koordinasi seluruh instansi/institusi yang terkait dalam mitigasi bencana banjir. Penanggulangan bencana baik tingkat daerah mapun pusat, terlebih dahulu berkoordinasi dengan BNPB dan BPBD.

Selain Pemerintah Pusat, pemerintah daerah dan BNPB, penanggulangan bencana khusnya pada mitigasi bencana banjir, dilakukan oleh lembaga swasta dan international. Peran lembaga swasta dan international dalam mitigasi bencana banjir antara lain membantu pengumpulan bantuan untuk disalurkan kepada korban bencana banjir bandang; membantu proses rehabilitasi dan rekonstruksi daerah yang terkena bencana; dan membantu penyediaan data berdasarkan hasil penelitian yang dilakukan secara independent oleh lembaga yang bersangkutan.

Dapat dilihat dari fungsi, tugas dan peran masing-masing stakeholder dalam penanganan mitigasi bencana banjir, baik pemerintah pusat, pemerintah daerah, BNPB dan lembaga swasta dan international, memiliki fungsi, tugas dan peran yang bebedabeda. Namun dapat dlihat dari uraian yang telah dipaparkan sebelumnya bahwa, BNPB dan BPBD merupakan instasi/lembaga yang tugas, fungsi dan perannya secara keseluruhan bergerak pada penanggulangan bencana khusnya dalam mitigasi bencana banjir.

\section{KESIMPULAN}

Mitigasi dalam manajemen bencana banjir merupakan langkah pengurangan resiko serta pemberian pengetahuan kepada masyarakat dalam penanganan bencana banjir. Dalam mitigasi bencana banjir merupakan tanggung jawab seluruh pihak, baik pemerintah pusat, pemerintah daerah, dan BNPB serta lembaga swasta dan international. Namun pada tugas, fungsi dan peran dalam kewenangan mitigasi bencana banjir sebagian besar dilakukan oleh BNPB dan atau BPBD. Berdasarkan hasil penelitian ditemukan bahwa peran setiap stakeholder telah ditentukan dalam Undang-undang No. 24 tahun 2007, dan dengan demikian, setiap tindakan dan aktivitas yang dilakukan oleh beragam stakeholder yang terlibat dalam mitigasi bencana banjir bandang akan berada dalam perlindungan UU tersebut.

\section{DAFTAR PUSTAKA}

Freeman, R.E., and Miles. 2006. Stakeholder : Theory and practice. Oxford University. New York.

Indrawan dan Poppy, 2014. Metodologi Penelitian. PT. Refika Aditama. Bandung.

Nurjanah dkk, 2013. Manajemen Bencana. Alfabeta. Bandng.

Soerjono Soekanto. 2009. Sosiologi Suatu Pengantar, Edisi Baru, Rajawali Pers Jakarta.

UN-ISDR. 2002. International Strategy for Disaster Reduction $(2002,2004)$.

W. Nick Carter. 1990. Disaster Management, Asian Development Bank.

\section{Sumber lain}

Pertanahan

Nasional (http://www.bpn.go.id)

Badan Search And RescueNasional (http://www.basarnas.go.id)

Badan Meteorologi, Klimatologi, dan Geofisika (http://www.bmkg.go.id)

Badan Pengkajian dan Penerapan Teknologi (http://www.bppt.go.id)

Badan Pusat Statistik (http://www.bps.go.id)

Direktoral Jenderal Bina Marga, Kementerian Pekerjaan Umum (http://www.pu.go.id)

Direktoral Jenderal Cipta Karya, Kementerian Pekerjaan Umum (http://www.pu.go.id)

Direktoral Jenderal Sumber Daya Air, Kementerian Pekerjaan Umum (http://www.pu.go.id)

Kementerian Komunikasi dan Informatika (http://kominfo.go.id)

Kementerian Dalam Negeri (http://www.depdagri.go.id)

Kementerian Energi dan Sumber Daya Mineral (http://www.esdm.go.id/badan-geologi/)

Kementerian

Kesehatan (http://www.depkes.go.id)

Kementerian

Keuangan 
Kementerian Pekerjaan Umum -Direktorat Sumber Daya Air (http://www.pu.go.id)

Lembaga Penerbangan dan Antariksa Nasional (http://www.lapan.go.id/)

Lembaga Ilmu Pengetahuan Indonesia (http://www.lipi.go.id)

Peraturan Presiden Nomor 24 Tahun 2010, Tupoksi Kementerian Negara.

Pramuka (http://www.pramuka.or.id)

Tagana (http://taganaindonesia.blogspot.com/) \& (http://tagana.depsos.go.id)

Undang-Undang Republik IndonesiaNomor2 Tahun 2002, Negara Kepolisian Republik Indonesia.

Undang-Undang Republik Indonesia Nomor 20 Tahun 2003, Sistem Pendidikan Nasional.

Undang-Undang Republik Indonesia Nomor 26 Tahun 2007, Penataan Ruang.

Undang-Undang Republik Indonesia Nomor 4 Tahun 2011, Informasi Geospasial.

Undang-undang Nomor 24 Tahun 2007 tentang Penanggulangan Bencana

Usulan Rencana Aksi untuk Meningkatkan Kemampuan Mitigasi Bencana Banjir Bandang di
Indonesia http://docplayer.info/172057Pedoman-manajemenpenanggulanganbencana banjir-bandang.html 